\title{
Outcome of minimally invasive percutaneous plate osteosynthesis (MIPPO) for closed comminuted fractures of upper metaphysis of Tibia
}

\author{
Shafeed T.P. ${ }^{1}$, Abdulla Sameer Jeeju ${ }^{2}$ \\ ${ }^{1}$ Dr. Shafeed T.P, Associate Professor, Department of Orthopaedics, PK DAS Medical College, Vaniamkulam, \\ Ottapalam, Palakkad, India, ${ }^{2}$ Dr. Abdulla Sameer Jeeju, Department of Orthopaedics, Kerala Medical College, Palakkad, \\ India
}

Correspondence Author: Dr. Shafeed T.P., Associate Professor, Department of Orthopaedics, PK DAS Medical College,Vaniamkulam P.O, Ottapalam, Palakkad District, Kerala, India. E-mail: shafeedmarakar@gmail.com

\begin{abstract}
Background: Management of complex metaphyseal fractures is usually complicated by articular extension, characterized by the difficulty of achieving accurate joint reconstruction and the sufficient stabilization without jeopardizing the usually severely traumatized soft tissue envelope. Minimally invasive percutaneous plate osteosynthesis (MIPPO) method of fracture fixation proposes the advantages of indirect fracture reduction and percutaneous submuscular implant placement. Methods: 20 patients with AO/ASIF 41A-B-C fractures of proximal tibia were followed up from December 2016 to June 2018. All the patients underwent Minimally invasive percutaneous plate osteosynthesis (MIPPO) with medial proximal tibial LCP. Clinical and radiological follow-up were recorded for 18 months. Results: Mean surgical time in minutes was 59.2. The average time for appearance of callus was 4 to 5 weeks and full weight bearing duration 20 to 38 weeks. Average range of movements for flexion 121.7 degree and extension 1.8 degree. Conclusion: MIPPO plating of proximal tibial fractures permits stable fixation, mobilization and avoid soft tissue related complications.
\end{abstract}

Keywords: Minimally invasive, Percutaneous plate, Osteosynthesis, Metaphyseal fractures, Proximal tibia.

\section{Introduction}

Fractures of the proximal tibia may involve a major weight-bearing joint and are serious injuries that frequently result in functional impairment [1]. To preserve the normal mechanical axis, ensure joint stability and restore a full range of motion. This is a formidable task, especially in the face of compromised soft tissues, variable bone quality and associated medical condition of the patient. Despite a plethora of article written since the middle of the twentieth century addressing the problems of classification and results of various treatment the optimal method of management remains controversial [2]. There are two categories of proximal tribal fractures articular and non-articular. Both these affect the knee alignment, stability and strength. The spectrum of injuries to the proximal tibia is so great that no single method of treatment has proven uniformly successful [3].

Manuscript Received: $18^{\text {th }}$ April 2019

Reviewed: $28^{\text {th }}$ April 2019

Author Corrected: $3^{\text {rd }}$ May 2019

Accepted for Publication: $8^{\text {th }}$ May 2019
The unique cross-sectional anatomy of the proximal tibia poses specific difficulties with regard to intramedullary nailing. Open plating techniques have potential for significant soft tissue complications including difficulty to close, wound breakdown and deep infection.

External fixation techniques are cumbersome and also present problems of pin tract infection, which may lead to septic arthritis of the knee under certain circumstances [4]. In cases with articular extension, external fixators may not be good option to achieve articular congruity. In the last two decades, one of the greatest advances in fracture care has been the concept of "biological plating" popularized by Ganz, Jacob, Mast, Gautier, Reudi and other surgical masters [5]. The treatment of closed comminuted metaphyseal fractures of upper end of tibia have evolved from casts, open plating, external fixators to a minimal invasive technique of plating. It is termed as MIPPO, minimally invasive percutaneous plate osteosynthesis. 


\section{Original Research Article}

A minimally invasive approach to such injuries improves wound healing, union rates and decrease the complication rates.

The minimally invasive percutaneous plate osteosynthesis (MIPPO) method of fracture fixation proposes the advantages of indirect fracture reduction and percutaneous, submuscular implant placement [6].

The plates bridge the fracture site with or without anatomical reduction of fracture fragment. The superiority of minimal invasive plating osteosynthesis in maintaining arterial vascularity and perfusion in cadaveric fusion has been well documented. The aim is to achieve good and maintain alignment, rotary stability and length, without disturbing the soft tissue attachment, and blood supply.

This idea of minimally invasive percutaneous plate osteosynthesis (MIPPO) assumed strong foundation when other methods of treatment failed. Moreover, minimal instrumentation, lesser hospital stay, familiar implants, less number of sutures, lesser pain, lesser post-operative complications and easier learning curve are distinct advantages of minimally invasive percutaneous plate osteosynthesis (MIPPO) for comminuted metaphyseal fractures of upper tibia.

\section{Aim}

To evaluate the outcome of closed comminuted fractures of upper metaphysic of tibia treated by minimally invasive percutaneous plate osteosynthesis (MIPPO). Another aim we pose is to compare the results of the study with that of other methods of treatment for similar fractures published in the literatures.

\section{Methodology}

Setting and type of Study: This is a prospective study and group included patients admitted with closed comminuted metaphyseal fracture of the upper end of tibia with or without epiphyseal / intra articular extension treated at our institutions between $1^{\text {st }}$ December 2016 and $1^{\text {st }}$ June 2018.

Sampling Methods: A non-random sampling was followed. The sample size includes a total 20 patients and 2 had lost to follow up. Thus the study included 18 patients. There were 14 men and 4 women.

Sample collection: Sample was collected based on inclusion and exclusion crietria.

\section{Selection criteria}

Inclusion criteria: Closed comminuted metaphyseal fractures of upper end of tibia with or without intra articular extension. AO/ASIF (41 A - B C)

Exclusion criteria: Compound fractures, Fractures in children, Pathologic fractures, Neurovascular injuries. The patients were operated following the same principles of fracture fixation. All the fractures were assessed with plain radiographs which included supine. AP and lateral views. The neurovascular status was evaluated clinically for every patient and a thorough evaluation of associated injuries was also done.

Poly traumatized patients were resuscitated and adequately splinted and radiographs were taken only after they were stabilized. Patients with severe swelling and soft tissue compromise were operated only after the swelling had subsided. All the fractures were treated by the technique of MIPPO. All patients underwent cancellous bone through a stab incision.

Instruments: Power drill/ Electric drill, Depth guage, $3.5 \mathrm{~mm} / 4.5 \mathrm{~mm}$ drill bits, Cortical/ cancellous locking screws

Implants: Medial Proximal Tibial LCP, 16 mm/32 mm cancellous locking screws, fully threaded cancellous screws with washers, $4.5 \mathrm{~mm}$ cortical locking screws.

\section{Surgical technique}

Step 1- The affected lower limb is painted with betadine and draped. A small $5 \mathrm{~mm}$ longitudinal incision is put proximal to the fracture site in the medial aspect of tibia.

Step 2 - The fracture is reduced by longitudinal traction and reduction checked under image intensifier(C-arm).

Step 3 - An aluminium template is slid along the medial aspect of tibia in the sub muscular plane along the fracture and contoured to the shape of the bone by manual pressure from outside and the ' $\mathrm{C}$ ' arm is used to note the length of the plate needed for fixation.

Step 4 - The Medial Proximal Tibial LCP is then slide along the same tunnel by manual pressure and fracture reduction is confirmed.

Step 5 - The screws are inserted on either side of the fracture by stab incision and confirmed by ' $\mathrm{C}$ ' arm. Ideally 3 screws are inserted away from the comminution on either side. 
Step 6 - Bone grafting is done to the fracture site when indicated through a stab incision and the incision are sutured and sterile padding applied. Cancellous bone graft from the contra lateral tibia was done in all 18 cases in the present study.

All patient had a post-operative evaluation of the fixation by X-ray. All the patient were put on $\mathrm{A} / \mathrm{K}$ slab for 2 week and then started on $2^{\text {nd }}$ post OP day and delayed in patient with associated injuries. In serve comminution, post operatively Thomas Splint was put and the AK cast put for 1 month.

The patients were mobilized non weight bearing walking for a period of 6-8 weeks and depending on the fracture pattern partial weight bearing done at 10 weeks and full weight bearing at an average of 20 weeks.

Follow up: All the patients in the study were followed up at 2 weeks, 4 weeks, 3 months, 6 months and 1 year and some patients even volunteered for further follow up.

\section{Results}

Table-1: Descriptive statistical

\begin{tabular}{|c|c|c|c|c|}
\hline \multirow{2}{*}{ Factors } & \multicolumn{2}{|c|}{ Range } & \multirow{2}{*}{ Mean } & Standard deviation \\
\cline { 2 - 5 } $\begin{array}{c}\text { Age } \\
\text { (in years) }\end{array}$ & 18 & 81 & 50.27 & 16.12 \\
\hline $\begin{array}{c}\text { Surgical time } \\
\text { (in minutes) }\end{array}$ & 39 & 88 & 59.22 & 12.06 \\
\hline $\begin{array}{c}\text { Blood loss } \\
\text { (in ml) }\end{array}$ & 34 & 74 & 45.33 & 1.79 \\
\hline $\begin{array}{c}\text { Imaging time } \\
\text { (in shots) }\end{array}$ & 7 & 14 & 11.05 & 0.78 \\
\hline $\begin{array}{c}\text { Callus } \\
\text { (in weeks) }\end{array}$ & 4 & 6 & 4.50 & 2.03 \\
\hline $\begin{array}{c}\text { FWB } \\
\text { (in weeks) }\end{array}$ & 17 & 26 & 20.38 & 1.79 \\
\hline
\end{tabular}

The age group ranged from 18 to 81 with average age of 50.27 years. Surgical time was recorded in minutes which included skin to skin suturing, The average (SD) time was 59.22 (12.06). Imaging time was recorded in terms of number of shots as ' $\mathrm{C}$ ' arm is vital for the placement of screws. Each shot was measured as $1 \mathrm{sec}$ at the voltage of $20 \mathrm{~mA}$. The average (SD) imaging time was 11.05 shots (1.79).

The average (SD) blood loss noted in this study was $45.33 \mathrm{ml}$ (9.25). It was calculated by the number of soaked gauzes and mops. Each fully soaked mop/gauze was considered to have $50 \mathrm{ml}$ and $5 \mathrm{ml}$ respectively. In poly traumatized patients this was calculated by the number of blood units transfused multiplied by the differences in hemoglobin levels before and after operation less the post-operative drainage.

The average (SD) time for appearance of callus was 4.5 weeks (0.78). Full weight bearing ranged from 17-26 weeks with average of 20.38 (2.03) 
Original Research Article

Table-2: Table showing pre-operative and post-operative factors' correlation with respect to age

\begin{tabular}{|c|c|c|c|c|c|}
\hline Factors & Age in years & Mean & $\begin{array}{l}\text { Standard } \\
\text { deviation }\end{array}$ & t-value & p-value \\
\hline \multirow{2}{*}{$\begin{array}{l}\text { Surgical time } \\
\text { (in minutes) }\end{array}$} & $<50$ & 56.11 & 14.54 & \multirow{2}{*}{1.101} & \multirow{2}{*}{ NS } \\
\hline & $>50$ & 62.33 & 8.70 & & \\
\hline \multirow{2}{*}{$\begin{array}{l}\text { Blood loss } \\
\text { (in } \mathrm{ml} \text { ) }\end{array}$} & $<50$ & 45.11 & 11.62 & \multirow{2}{*}{0.099} & \multirow{2}{*}{ NS } \\
\hline & $>50$ & 45.55 & 6.83 & & \\
\hline \multirow{2}{*}{$\begin{array}{l}\text { Imaging time } \\
\text { (in shots) }\end{array}$} & $<50$ & 10.55 & 1.58 & \multirow{2}{*}{1.195} & \multirow{2}{*}{ NS } \\
\hline & $>50$ & 11.55 & 1.94 & & \\
\hline \multirow{2}{*}{$\begin{array}{l}\text { Callus } \\
\text { (in weeks) }\end{array}$} & $<50$ & 4.22 & 0.66 & \multirow{2}{*}{1.562} & \multirow{2}{*}{ NS } \\
\hline & $>50$ & 4.77 & 0.83 & & \\
\hline \multirow{2}{*}{$\begin{array}{l}\text { FWB } \\
\text { (in weeks) }\end{array}$} & $<50$ & 20.66 & 2.29 & \multirow{2}{*}{0.568} & \multirow{2}{*}{ NS } \\
\hline & $>50$ & 20.11 & 1.83 & & \\
\hline
\end{tabular}

NS - > Not significant statistically

FWB - Full weight bearing

Neither the pre-operative nor the post-operative factors studied showed any correlation to the patients' age.

Table-3: Per operative and post-operative correlation in respect of sex

Males - 14(n) Females- 4(n)

\begin{tabular}{|c|c|c|c|c|c|}
\hline Factors & Sex & Mean & Standard deviation & T value & $P$ value \\
\hline \multirow{2}{*}{$\begin{array}{l}\text { Surgical } \\
\text { Time (in minutes) }\end{array}$} & $\mathrm{F}$ & 62.00 & 10.23 & \multirow{2}{*}{0.511} & \multirow{2}{*}{ NS } \\
\hline & $\mathrm{M}$ & 58.42 & 12.76 & & \\
\hline \multirow{2}{*}{$\begin{array}{l}\text { Blood } \\
\text { Loss } \\
\text { (in } \mathrm{ml} \text { ) }\end{array}$} & $\mathrm{F}$ & 42.50 & 3.78 & \multirow[b]{2}{*}{0.683} & \multirow[b]{2}{*}{ NS } \\
\hline & $\mathrm{M}$ & 46.14 & 10.27 & & \\
\hline \multirow{2}{*}{$\begin{array}{l}\text { Imaging time } \\
\text { (in shots) }\end{array}$} & $\mathrm{F}$ & 11.25 & 0.95 & \multirow{2}{*}{0.238} & \multirow{2}{*}{ NS } \\
\hline & $\mathrm{M}$ & 11.00 & 2.00 & & \\
\hline \multirow{2}{*}{$\begin{array}{l}\text { Callus } \\
\text { (in weeks) }\end{array}$} & $\mathrm{F}$ & 4.75 & 0.95 & \multirow{2}{*}{0.711} & \multirow{2}{*}{ NS } \\
\hline & $\mathrm{M}$ & 4.42 & 0.75 & & \\
\hline \multirow{2}{*}{$\begin{array}{l}\text { FWB } \\
\text { (in weeks) }\end{array}$} & $\mathrm{F}$ & 21.00 & 2.16 & \multirow{2}{*}{0.670} & \multirow{2}{*}{ NS } \\
\hline & $\mathrm{M}$ & 20.21 & 2.04 & & \\
\hline
\end{tabular}

NS - Not significant statically

FWB - Full weight bearing

Factors studied showed no significant changes with respect to sex.

The statistical analysis reveals that there is no significant difference between age and sex. The outcome of the factors studied i.e. Surgical time, blood loss, imaging time, callus and full weight bearing (FWB).

\section{Discussion}

Minimally invasive percutaneous plate osteosynthesis is a new concept in plate osteosynthesis that attempts to combine the advantages of minimally invasive surgical approaches and anatomically preshaped plates. This technique limits the surgical trauma inflicted, while stabilizing the fracture adequately.

The stability provided by such a construct allows treatment of unstable complex tibial metaphyseal fractures with single medially based plate that previously required dual plating, a circular fixator, or a combination of both. 


\section{Original Research Article}

The advantage of MIPPO is that this technique can be done in a routine orthopaedic setup using the basic Orthopaedic instruments and implants. Only a ' $\mathrm{C}$ ' aim is an additional necessity which is available in most of the present Orthopaedic set ups. Percutaneous plating techniques offer surgeons a good method of bone stabilization in patients with complex fracture of tibia with severely compromised soft tissue and injuries with intraarticular or periarticular extension. Percutaneous plating minimizes soft tissue stripping preserves vascular pedicle and allows the osteogenic fracture heamatoma to remain essentially undisturbed.

This technique seems to considerably reduce the risk of infection or soft tissue damage and allows for rapid mobilization of limb and patient.

Because these fractures are not visualized, length, rotation and angular alignment must be determined indirectly during surgery. Therefore, it must be understood that these methods are challenging technically and that special attention must be given to prevent malalignment. The implant used in this study was Medial Proximal Tibial LCP and a medial approach was done in contrast with UMC Alabama, Berlin study where a lateral approach was made with a LISS system, which employs a fixed angled plate inserted with a jig and locking screw $[7,8,9]$.

A prophylactic bone grafting was done in the present study keeping in view the consequences of delayed union and nonunion as a second surgery would increase the risk of anesthesia as well as hospital cost which would be an additional burden to the already constrained patients. This was in contrast to the other studies where a bone grafting was reserved for compound fractures delayed union, nonunion and in serve bone loses. In the present study there were 18 patients and among them 14 were females. The average age of the patients was 50.27 Range (18-81). Majority the patients sustained injury following RTA (77.8\%) which is similar to the findings in other studies.

Table-4: Table comparing variables with other studies

\begin{tabular}{|c|c|c|c|c|}
\hline Study & Patients & M:f & Age & Mode of injury \\
\hline UMC clinical trial $^{\mathbf{7}}$ & 53 & $38: 15$ & $44(16-82)$ & NA \\
\hline Berlin study $^{\mathbf{1}}$ & 16 & $14: 2$ & $42(22-59)$ & NA \\
\hline Alabama study & 34 & $30: 4$ & $39(19-76)$ & $\begin{array}{c}24-\text { RTA } \\
8-\text { FALL } \\
2-\text { ASSAULTS }\end{array}$ \\
\hline Collinge et al $^{\mathbf{1 0}}$ & 17 & NA & $32(14-56)$ & $\begin{array}{c}15-\text { RTA } \\
\text { Fall - } 1 / \text { Air } \\
\text { Crash - }\end{array}$ \\
\hline Present study & 20 & $16: 4$ & $*(50) 18-81$ & $\begin{array}{c}16-\text { RTA } \\
2-\text { FALL } \\
2-\text { Assaults }\end{array}$ \\
\hline
\end{tabular}

NA - Not Available

* Corrected value

This is probably because of increasing vehicular traffic and violation of traffic rules. The right side was more affected in the present study and no related references are there in other studies as the two wheeler accidents constituted majority of the RTA, the right lower limb presumably more prone to injury in the system of right hand drive. The AO/OTA Classification for fracture and Tscherne's classification of closed fracture were adopted in the present study.

As per these classification present study featured 3(41 A2), 10 (41 A3), 4(41-C2) and 1 (41-C3). In the Berlin study there were 3(41A) fractures, 12(41C) fractures [9]. The other studies had always included the diaphyseal fracture i.e. (AO 42). The closed fracture classification included T scherne type I - 12, type II -3 , type III -1 and type $\mathrm{O}-2$. In this section we explore the various intra - operative and post-operative variables [11].

In UMC study, the surgical time was 56 minutes and for BERLIN study, the surgical time was 122 minutes and imaging time 4 minutes. Present study showed surgical time to 59 minutes, blood loss $45.33 \mathrm{ml}$ and imaging times. 


\section{The range of motion}

Table-5: Table comparing functional outcome with other studies

\begin{tabular}{|c|c|c|c|}
\hline STUDY & ROM & Alignment & Shortening \\
\hline UMC clinical trial $^{\mathbf{7}}$ & $1^{0}-116^{0}$ & $8^{0}-$ Varus & NA \\
\hline Berlin study $^{\mathbf{8}}$ & $0^{0}-105^{0}$ & $\begin{array}{c}6^{0} \text { Varus } \\
60 \text { Valgus }\end{array}$ & NA \\
\hline Alabama study $^{\mathbf{9}}$ & $2^{0}-116^{0}$ & $\begin{array}{c}50 \text { Valgus } \\
100 \text { procurvatum }\end{array}$ & NA \\
\hline Collinge et al $^{\mathbf{1 0}}$ & $0^{0}-130^{0}$ & NA & $\begin{array}{c}2 \mathrm{~mm} \\
(0-15 \mathrm{~min})\end{array}$ \\
\hline Present study & $0^{0}-134^{0}$ & $\begin{array}{c}\text { Varus } 3.670 \\
\text { Valgus } 4.160\end{array}$ \\
\hline
\end{tabular}

The values noted in the present study were within the limits proposed by TRAFTON [12]. No rotational deformities were noted in the present study. Malalignment has been reported by various authors in a range of $14-33 \%$ on with varus malalignment, the most common and debilitating form [13].

Complication- In the present study one patient (No. 2) underwent fasciotomy for impending compartment syndrome and no post-operative nerve palsies were noted.

However, one patient had developed superficial infection 5.5\% (Pt. No: 14) which led to wound dehiscence and plate exposure at the fracture site which was regularly dressed and antibiotics were administered and secondary suturing done. The plate was removed at the fracture union.

Table-6: Table comparing complications of surgery with other studies

\begin{tabular}{|c|c|c|c|c|}
\hline Study & Fasciotomy & $\begin{array}{c}\text { Superfical } \\
\text { Infection }\end{array}$ & $\begin{array}{c}\text { Osteom } \\
\text { Yelitis }\end{array}$ & $\begin{array}{c}\text { Implant } \\
\text { Loosening }\end{array}$ \\
\hline UMC clinical trial $^{7}$ & NA & 3 & NIL & NA \\
\hline Berlin study $^{8}$ & 4 & NIL & NIL & 1 \\
\hline Alabama study $^{9}$ & NIL & NIL & NIL & NIL \\
\hline Collinge et al $^{10}$ & NA & NIL & 1 & NA \\
\hline Present study & 1 & 1 & NIL & NIL \\
\hline
\end{tabular}

NA - Not available

Deep infection and osteomyelitis remain a significant problem with rates of $80 \%$ or more and $33-40 \%$ for osteomyelitis $[14,15]$. There was a technical difficulty in removing the plates after fracture union as there was bone outgrowth over the plates which necessitated us to put a traditional incision for plate removal. However, this traditional incision did have no bearing in the final outcome.

\section{Conclusion}

- Minimally invasive percutaneous plate osteosynthesis is a simple but effective method for the treatment for closed comminuted metaphyseal fractures of upper end of tibia with or without articular extension where the treatment options are limited.

- MIPPO carries all the advantages of a closed procedure, eliminates most of the disadvantages of conventional open plating, at the same time provides all the benefits of plate osteosynthesis.

- Patient acceptance for the procedure is very high due to the small incision and lesser pain.

- Prophylactic bone grafting is better for prevention of delayed union and non-union.

- Statistically there is no significance of the age and sex of the patients on the outcome of the fractures.

\section{What the present study add to existing knowledge?}

Many literatures emphasize on doing open surgery to get a good alignment but in this study the varus and valgus mal-alignment was almost nil and has all the advantages of closed reduction and plate osteosynthesis 


\section{Original Research Article}

which makes a meaningful addition to existing literature.

\section{Author's contribution}

1. Dr. Shafeed $\mathbf{T}$ P: Doing the surgeries for the patients, documenting the data and collecting references for the study.

2. Dr. Abdulla Sameer Jeeju: Assisting for the surgeries, examining the patients during the regular follow-up and entering data for statistical analysis.

Funding: No funding was received for this study from any institute or company.

Conflict of interest: None declared.

Funding: Nil, Permission from IRB: Yes

\section{References}

1. Rockwood and Green Fractures in Adult Vol. 2 10th Ed. Pages $1802-1841,1939-40$

2. Koval KJ, Helfet DL. Tibial Plateau Fractures: Evaluation and Treatment. J Am Acad Orthop Surg. 1995;3(2):86-94.

3. Buehler KC, Green J, Woll TS, Duwelius PJ. A technique for intramedullary nailing of proximal third tibia fractures. J Orthop Trauma. 1997;11(3):218-23.

4. Bal GK, Kuo RS, Chapman JR, Henley MB, Benirschke SK, Claudi BF. The anterior T-frame external fixator for high-energy proximal tibial fractures. Clin Orthop Relat Res. 2000;(380):23440.DOI:10.1097/00003086-200011000-00032

5. Lang GJ, Cohen BE, Bosse MJ, Kellam JF. Proximal third tibial shaft fractures. Should they be nailed? Clin Orthop Relat Res. 1995;(315):64-74.

6. Gerber A, Gang R. Combined Internal/External Osteosynthesis a biological approach to the treatment of complex fractures of the proximal tibia. J Injury. 1998;29(3):C22-8. DOI: https://doi.org/10.1016/S00201383(98) 95005-7
7. Cole PA MD, M Zlowodsi MD, Kegor P.J. MD. LISS for fracture of the proximal tibia: indications, surgical technique and preliminary results of UMC clinical trial. J. Injury. 2003;34(1):A16-29. DOI: https:// doi.org/10.1016/S0020-1383(03)00254-7.

8. Schütz M, Kääb MJ, Haas N. Stabilization of proximal tibial fractures with the LIS-System: early clinical experience in Berlin. Injury. 2003;34(1):A30-5. DOI: https://doi.org/10.1016/S0020-1383(03)00255-9

9. Stannard JP, Wilson TC, Volgas DA, Alonso JE. Fracture stabilization of proximal tibial fractures with the proximal tibial LIS-System: early experience in Birmingham, Alabama. Injury. 2003;34(1):A36-42. DOI: https://doi.org/10.1016/S0020-1383(03)00256-0

10. Collinge C, Sanders R, DiPasquale T. Treatment of complex tibial periarticular fractures using percutaneous techniques. Clin Orthop Relat Res. 2000;(375):69-77. DOI:10.1097/00003086-200006000-00009

11. Hutson JJ Jr, Zych GA. Infections in periarticular fractures of the lower extremity treated with tensioned wire hybrid fixators. J Orthop Trauma. 1998;12(3):214-8.

12. Tarr RR, Resnick CT, Wagner KS, Sarmiento AU. Changes in tibiotalar joint contact areas following experimentally induced tibial angular deformities. Clin Orthop Relat Res. 1985;(199):72-80.

13. Mubarak SJ, Owen CA, Hargens AR, Garetto LP, Akeson WH. Acute compartment syndromes: diagnosis and treatment with the aid of the wick catheter. J Bone Joint Surg Am. 1978;60(8):1091-5.

14. Weiner LS, Kelly M, Yang E, Steur J, Watnick N, Evans M, Bergman M. The use of combination internal fixation and hybrid external fixation in severe proximal tibia fractures. J Orthop Trauma. 1995;9(3):244-50.

15. Geller J, Tornetta P 3rd, Tiburzi D, Kummer F, Koval K. Tension wire position for hybrid external fixation of the proximal tibia. J. Ortho Trauma. 2000;14(7):502-504.

\section{How to cite this article?}

Shafeed T.P., Abdulla Sameer Jeeju. Outcome of minimally invasive percutaneous plate osteosynthesis (MIPPO) for closed comminuted fractures of upper metaphysis of Tibia. Surgical Update: Int J surg Orthopedics. 2019;5 (3):146-152. doi:10.17511/ijoso.2019.i03.04. 